\title{
Morphology and Markedness: On Verb Switching in Biblical Hebrew Poetry
}

\author{
Elizabeth Robar \\ https://orcid.org/0000-0002-1584-5941 \\ Cambridge Digital Bible Research, United Kingdom \\ elizabeth.robar@cdbr.org
}

\begin{abstract}
Historically, grammarians have viewed tenses as simple, unanalysable pieces of grammatical information. Portmanteau tenses may combine tense, aspect, and modality, but these are the main categories. Suzanne Fleischman has proposed a radically new paradigm in which not only verbal forms but entire discourse contexts are analysed as clusters of oppositional properties to which markedness values apply. It is in the interaction of the cluster of properties associated with a verbal form and those associated with its discourse context that we find the locus of verbal meaning. This interactive meaning is illustrated by examples from Psalm 18, demonstrating that morphological forms have the effect of either drawing non-prototypical situations closer to the prototype or drawing situations farther away from the prototype.
\end{abstract}

Keywords: Hebrew; tense; aspect; discourse; morphology

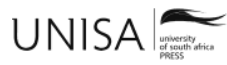




\section{Introduction}

The standard grammatical analysis of verbs, within biblical studies and more broadly, generally stays within the limits of tense, aspect, and modality (TAM) and relegates pragmatic uses to discourse grammar and implicatures. TAM, it is argued, is the "basic meaning" and anything pragmatic is secondary. ${ }^{1}$

Having laid this foundation, it is inevitable that anxiety should ensue about the abundance of "ungrammatical" uses of verbs, when their semantics do not align with their alleged "basic meaning." One means of relieving this anxiety is to argue that, if the basic semantics could have been understood already by the context, then perhaps the redundant TAM morphology (redundant because the context already provided it) is recycled for other (generally pragmatic) purposes.

Suzanne Fleischman (1990) takes this line of reasoning a step farther when she argues that "an alternative to the traditional view of tenses [conjugations] as simple, unanalysable pieces of grammatical information [with only TAM] is to view them as clusters of oppositional properties to which markedness values apply" (Fleischman 1990, 56). This proposal motivates the current essay.

\section{The French Passé Simple + Past Narrative}

As a Medieval-French scholar, Fleischman begins with the passé simple (preterite), which is the defining verb of a past-time historical narrative. The passé simple is distinctive in being restricted to the written register, and it has become synonymous with formal (objective) "history." Whereas "discourse," in the narrow sense, is the presentthe current observation of life as it unfolds before there is a chance to establish links or causes - "history" embodies the distant, objective, factual linking together of the past.

Table 1: Properties of both the passé simple and past-time narrative

\begin{tabular}{llll}
\hline Referential & Textual & Expressive & Metalinguistic \\
\hline + Past time & + Linked events & + Realis & + Diegesis (i.e., \\
+ Perfective aspect & + Foreground & + Distant & narration) \\
+ Semelfactive & & + Objective &
\end{tabular}

Categorised by the four different levels of the language system, ${ }^{2}$ the full cluster of properties of the passé simple (and consequently its default context, past-time narrative, on which see below) are illustrated in Table 1.

1 So, e.g., Hatav (1997); Gentry (1998); Moomo (2004); Cook (2012, 272-75). The standard approach is reflected in Joosten's $(2012,110)$ comment: "In addition to the basic, paradigmatic function of a verbal form, a number of secondary, context-conditioned functions may exist."

2 Her categories of the linguistic system are largely based on and modified from those of Halliday and Hasan (1976, 26-30) and Traugott (1982, 247-48). 
At the referential level, the prototypical event referred to by the passé simple has past time reference, perfective aspect, and refers to events that are semelfactive (occur only once). At the textual level, these events are linked (often sequentially) and constitute the foreground or main plot line. At the expressive level, prototypical events are realis and presented from a distant, objective perspective. From a metalinguistic level, prototypical events are presented diegetically (as a narrative, "telling"), rather than mimetically (describing, "showing"). ${ }^{3}$

\section{From Verbal Form to Discourse Context}

The properties of narrative derive from its most common form, the preterite. That is, the associations hearers have with the form are transferred to a set of expectations or norms for an entire discourse context. The definition of the discourse context, therefore, is not formal, but must be cognitive. ${ }^{4}$ The prototypical properties of the preterite become the cognitive background for a past-time narrative. This provides an entire cluster of expectations that are assumed (unless overridden) and which become the backdrop for interaction with all the various verbal forms available. That is, use of the preterite within a past-time narrative will confirm the default expectations, but uses of non-preterites will assert a different property (e.g., imperfectivity, or irrealis) against the backdrop of the narrative. The speaker has the ability to choose the default form, the preterite, or to choose otherwise. Herein lies the beginning of choice which enables the art of rhetoric and literature. ${ }^{5}$

\section{Markedness}

"Markedness" was first introduced into linguistics to designate a very specific idea in the domain of phonology. Trubetzkoy (Trubetzkoy 1939, 60-69) ${ }^{6}$ argued that not phonemes, but oppositions between phonemes played the main role (die Hauptrolle) in a phonological system. ${ }^{7}$ The defining feature of an opposition was its mark, as demonstrated in the privative relationship of a bilateral opposition between members distinguished by the presence or absence of a given feature (e.g., voicing in voiced vs. voiceless phonemes).

3 Narrative (diegesis) is here identified by the behaviour of the reference point during the unfolding of the events: If the reference point is updated with each event on the plotline, it is narrative/diegesis. If the reference point constantly returns to a given reference point, it is mimesis, or description that remains anchored.

4 In other words, the form itself only "profiles" (i.e., expresses) basic semantic parameters that pervade all cognitive activity and — to put it negatively — are not unique to language (see Langacker 2008, 14760; Evans and Green 2006, 386-96, 624-40).

5 See Fleischmann (1990, 61-63).

6 See Trubetzkoy (1969) for English translation.

7 See Dixon (2009, 235-36). 
After Trubetzkoy, the Russian Formalist Roman Jakobson expanded the term to other grammatical (e.g., perfective vs. imperfective), semantic (e.g., duck vs. drake), and even cultural (e.g., life vs. death) domains. ${ }^{8}$ Andersen $(2001,25)$ argued persuasively for "the reality of markedness as a principle of cognitive organization that is reflected in human behaviour and apparently fundamental to it." This paper uses the term markedness to refer to the interaction of forms based on the presence, absence, or irrelevance of a particular feature (the "mark"). The word "drake" is always marked for maleness (+ male), the word "duck" can be marked for femaleness (- male) or it can equally be unmarked, in which case gender is considered unspecified (0 male). In Fleischman's terms, the presence, absence or irrelevance of given features thereby give rise to plus interpretations, minus interpretations, and zero interpretations, such as "male" (+ male), "female" (- male) or "irrelevant" (0 male).

\section{Pragmatic Unmarking}

The interpretation of a feature is not only dependent, however, on its presence (or absence or irrelevance) in a given word. The interpretation is also dependent on its presence in the already established context.

[I]n contexts that are themselves marked, the normally marked member of an opposition is the one most commonly encountered. This is an instantiation of the general phenomenon of "pragmatic unmarking," whereby a marked item loses its distinctiveness (its mark) in a particular context through frequency of use. (Fleischmann 1990, 54)

If a verbal form is marked for past time, then its default discourse context is therefore also marked for past time. When the marked verbal form appears within the marked discourse context, it no longer "adds" the meaning of past time, because that meaning was already present, due to the context.

\section{Discourse Contexts: Definition vs. Prototypical Presentation}

Recognising this interaction between a morphological form and its context can correct a certain misconception in Biblical Hebrew studies. The field often equates the two, as if the verbal forms defined the "discourse types." first cognitively and only, derivatively, in formal terms. ${ }^{11}$ A given form of discourse can

8 See Jakobson's (1975) letter to Trubetzkoy, quoted in Waugh (1982, 300-1).

9 Haspelmath (2006) has helpfully critiqued the irresponsible use of the term, but, when applied judiciously (Dixon 2009, 235), it remains a powerful explanatory framework.

10 Cf. critiques of Longacre's discourse types (Robar 2014, 67-72, 148-52) and, more recently, Notarius's $(2013,31)$ adoption of them. See also Robar's (forthcoming) critique of Notarius.

11 This false sense of the unidirectionality of dependence fails to recognise the well-known phenomenon of "the hermeneutic circle" (see George 2020). Briefly defined, a whole is constructed when a part is encountered and, subsequently, those parts are refined as the whole is further encountered. More pertinently, verb forms allow the speaker/listener to trace and track complex conceptualisations which 
exist without its most characteristic form: history can be narrated, according to our default expectations, with a preterite form. Or, it can verge closer to performance, sometimes to our discomfort, with an abundance of other forms. ${ }^{12}$ But, in the presence or absence of preterites, it remains history nonetheless: a sequential telling of past events. We thus distinguish between the definition of history (a sequential telling of past events) and expectations for how it is prototypically presented (past time reference, perfective aspect, etc.).

\section{Interaction of Form and Context}

If a discourse context thus has, by common cultural assent, a full array of default properties, what happens when a non-default verbal form is used? One of Fleischman's $(1990,55)$ principal claims is that

when in a narrative the [present] — or any tense other than the [preterite] — is chosen, the narrator's objective (often unconscious) is to neutralize one or more of the properties that collectively define [preterite] as the unmarked tense of narration and in turn define the norms for narrative discourse.

When any particular form is used, it is the point of interaction between its own cluster of properties and that cluster of properties belonging to the discourse context that will determine the effect. The default form will match the discourse context fully, so there will be no further effect. Any other form will not align fully with the discourse context and will give rise to various effects. The effects will depend on the combination of form and context, such that the same form will have a different effect in different contexts.

This is the well-explored phenomenon of figure and ground interaction, ${ }^{13}$ which recognises that what the human mind perceives is always from the interaction of a figure (or foreground) against a ground (or background). Light grey against black appears nearly white, whereas the same light grey against white can appear quite dark. Red stands out starkly against white, but against a similar red background it blends in and becomes unremarkable. The effect of a given object thus depends both on the features of that object as well as the features of its context. The same is true of verbal forms: the effect of a verbal form depends not only on the form, but on the interaction of its own features with that of its context.

are expressed by the discourse. Nevertheless, they are dependent on that discourse for both their referential and pragmatic effects (see Fauconnier 1997, 72-98; Janda 2019, 199-209).

12 Compare "Wellington defeated Napoleon at the Battle of Waterloo, and Napoleon was never able to recover" (preterites) and "In 1815 Wellington defeats Napoleon at the Battle of Waterloo. Napoleon will never recover" (present and future tenses). See below.

13 E.g., Talmy (2000, 311-44), Rubin (2001, 225-28), Evans and Green (2006, 65-70), Langacker (2008, $58-60)$. 


\section{Tense Switching}

Locating the perceived effect of a verbal form in the interaction of form and context has begun to revolutionise grammar. Scholars of Romance languages have struggled (as have scholars of Biblical Hebrew) over "tense switching," 14 the varying of morphological verbal forms contrary to grammatical expectations. Tense switching is indeed problematic when grammatical expectations depend on the form alone. However, if the effect of a given tense is dependent on its context as well as its form, then, rather than being unexpected that a given form would exhibit different behaviours in different contexts, it becomes expected that the same form, in different contexts, would have a different effect. ${ }^{15}$ Consider the following conversational story:

Past-time narrative (with present tense forms in italics):

I went to SBL last year and nobody was wearing face masks. We mingled freely; we weren't afraid to breathe in each other's space.

So, a paper is being presented, and a latecomer slips into the room. He stands awkwardly for a moment; he surveys the audience. He finds an empty seat and takes it, unapologetically rubbing elbows and shoulders and knees with people on both sides.

My flight home was delayed and we walked for hours around the Phoenix airport. We trudged from one gate to the next as we were reassigned planes, again and again. Again and again, we plopped in adjacent seats and whiled away the time.

Goodness, I think I must have touched a dozen people!

\section{Narration and Performance}

This story is unambiguously a past-time narrative, even with its abundance of present tense forms. Nessa Wolfson $(1978,1979)$ has argued persuasively that, when we actually tell stories, we vary between telling and showing: between narration and performance. The more we use direct speech, asides, repetition, expressive sounds and sound effects, and similar features, the closer we come to the prototype of a "performed story." Of great significance for the present essay is her finding that, the more fully a story is performed, the more likely it is to exhibit tense switching. ${ }^{16}$

14 See Comrie (1985, 102-21) on tense-switching.

15 The idea of clusters of features interacting with the discourse would explain the variety of effects observed for tense-switching (in languages that grammatically express tense) in recent studies; see, e.g., Sakita (2002, 43-78); Wei-Lun (2019); Verhagen (2019); Nijk (2019); Al-Heeh (2020). Cf. the quote from Myhill $(1992,90)$ : "in the great majority of cases, a variety of different factors affect the choice of which form to use, so that marking in individual cases is determined by a number of factors operating simultaneously" (quoted in Sakita 2002, 229).

16 This is a foundational premise for Fleischman (1990). 
In this little story initiated in the past tense, the effect of switching to the present tense was to take a step closer to performing the story, having it unfold before the eyes, rather than simply having it be narrated as a neat package. In the movement from narration closer to performance, the locus of meaning (as perceived by the audience) also shifts. In narration, the meaning is "in the text," whereas in performance, the meaning is "in the context," in the implications of communicative acts. For readers attend to what is written, whereas listeners attend to what is meant. ${ }^{17}$

When a non-default or marked form is used in a given discourse context, it injects into the context some flavour of its own cluster of properties. When a present is used in a past time narrative in English or in Romance languages, we have now seen how it inches the story closer to being performed rather than simply being narrated. This movement, however slight, bears with it a host of potential ramifications for interpretation.

\section{Analysis of Biblical Hebrew}

Although Fleischman's own work was limited to Romance languages and English, she ponders a "potential universality" (Fleischman 1990, 12) for these clusters of properties and their implications. The remainder of this essay will constitute an investigation of the validity of this model in Biblical Hebrew, specifically in the interaction between morphological form and discourse context in Psalm 18. ${ }^{18}$

\section{Assumptions}

The following are assumed:

(1) Narrative is prototypically a series of sequential punctual events presented in an objective fashion (Fleischmann 1989; Fleischmann 1990, 101; Herman 2009, 75104; Lee 2020, 10-13). ${ }^{19}$

(2) Narrative can be either past time or future time. ${ }^{20}$

17 Fleischman (1990, 9).

18 The variation in verbal morphology within this psalm famously "sticks out" (fällt...auf; Saur 2014, 51) from our normal expectations of Hebrew verbs.

19 See Dancygier (2011, 23-29) for a broader cognitive discussion and characterisation of narrative.

20 This view assumes that there is an indicative future tense, distinct from modal forms. See Comrie (1985, 43-48); Dixon (2005, 210-14; 2012, 9-22, 42). Although Fleischmann (1982) concludes from her diachronic study of Romance languages that the future is, in fact, tied to modality, as Lyon (1983) points out, she does not consider languages outside of Latin and the Romance languages, nor does she justify why the future cannot be thought of in the same way as other temporal categories (Lyon 1983, 482). 
(3) Description is prototypically of non-sequential durative situations. It is not timebound but takes its time reference from the context. With no context, it defaults to present tense (Fleischman 1990, 61-63, 65-66; Herman 2009, 89-92). ${ }^{21}$

\section{Properties Addressed}

Rather than addressing every property identified by Fleischman, we attend here to only the following four key features:

(1) Situation type (durative vs. punctual)

(2) Discourse mode (narrative vs. description)

(3) Time reference (past, present, future, timeless/unspecified)

(4) Verbal conjugation (yiqtol, qatal) ${ }^{22}$

The situation type derives from the idea of lexical aspect (i.e., the inherent structure of verbs with reference to time) but recognises that the full situation (including subject and object definiteness and quantification, as well as tense) is more useful, since lexical aspect has scope over only a verb ("to smoke") whereas situation type has scope over an entire predicate (“to smoke a cigarette," Fleischman 1990, 22). ${ }^{23}$

Situation type has been simplified, in this paper, to the opposition between durative and punctual, following the seminal work by Vendler as revised by Comrie and Smith.

Table 2: Situation types (see Vendler 1957; Comrie 1976; Smith 1997)

Dynamic Stative

\begin{tabular}{llll}
\hline & Telic (+ telic) & Atelic (- telic) & \multirow{2}{*}{ State } \\
Durative (+ duration) & Accomplishment & Activity & \\
Punctual (- duration) & Achievement & Semelfactive & \\
\hline
\end{tabular}

The combination of these assumptions and features yields the expectation that unmarked narrative events will be punctual by nature (situation type) and presented punctually and objectively (morphologically); events either not by nature punctual or not presented

21 More specifically, within narration (diegesis), the reference point is updated by each (prototypical) event, namely $\mathrm{A}$, then $\mathrm{B}$, then $\mathrm{C}$, with the reference point regularly updated to after $\mathrm{A}$, then after $\mathrm{B}$, then after C. By contrast, within description (mimesis), the reference point is not updated at all but remains the same throughout, e.g., A and B and C simultaneously, with no sequencing or progression. This is the difference between a preterite and a perfect, with the preterite being the prototype of narration, advancing the reference point, while a perfect belongs to description, observing the result of an (inferred) previous action that does not change the reference point. For a thorough discussion of the history of scholarship and differences between narration and description, see Koopman (2018, 15-40). Koopman's characterisation of description, following Wolf (2007), largely corresponds to the definition here.

22 For the purposes of this paper, only these two conjugations are addressed.

23 Cf. "Max coughed" (punctual) vs. "Max coughed for ten minutes" (durative) (Evans 2007, 163). 
punctually or objectively will stand out as marked. Similarly, non-sequential, durative situations will be assumed to be descriptions unless their morphology or context pull them in a different direction; and sequential or non-durative situations that are presented as descriptions will be considered marked in some way.

\section{Psalm 18}

Below, sections of text are presented according to situation type, discourse mode, and verbal morphology. Situation type and discourse mode will be indicated by the background shading of the text (light grey for durative and mimesis and dark grey for punctual and diegesis) and verbal morphology will be indicated by bold text, with light grey background for yiqtol forms and dark grey background for qatal forms. Where forms match their default durative situation type, they will blend in; where they do not, the background will stand out. Where situation types match their default discourse mode, they will likewise blend in; where they do not, one colour will be embedded within another.
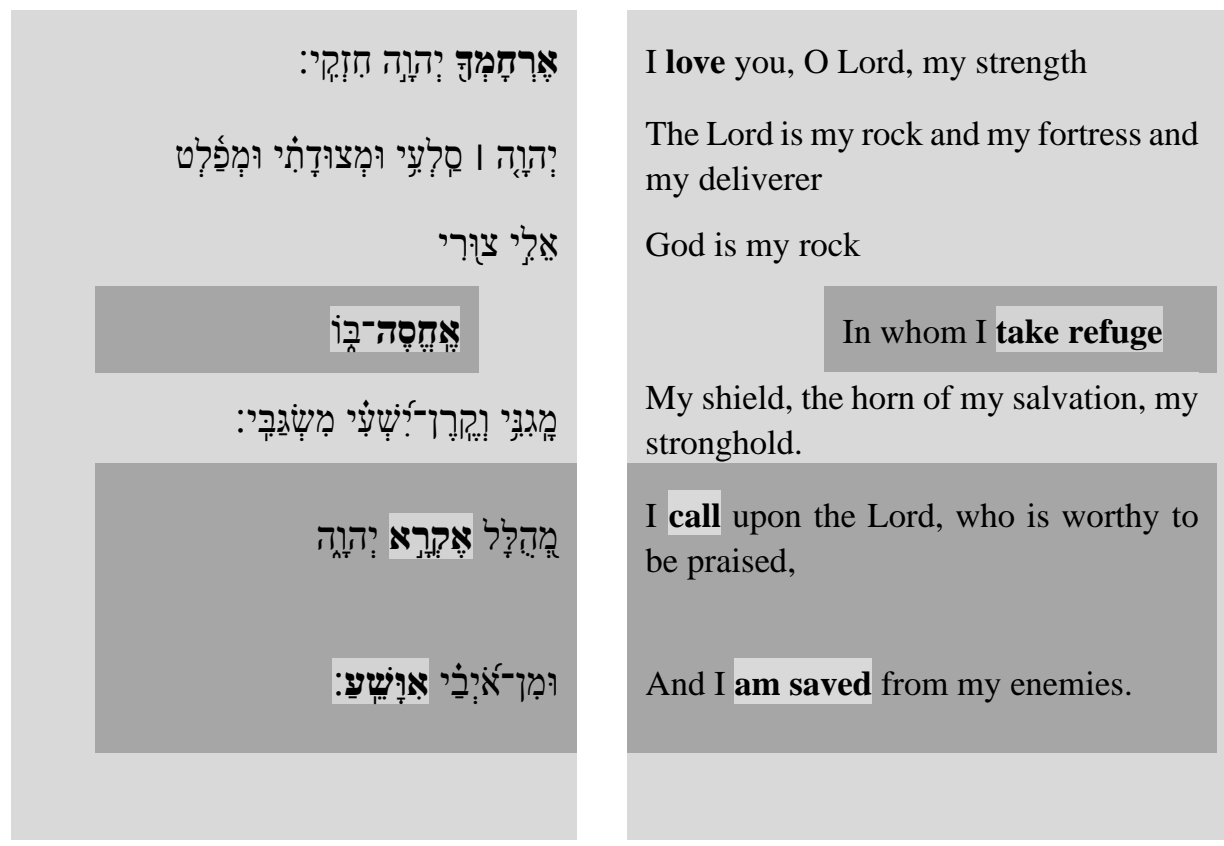

Figure 1: Psalm 18:2-4 presented according to discourse mode, situation type and verbal conjugation

After the superscription, the psalm opens with ויאמר (not represented here) followed by the text as displayed above. The opening "I love you" is durative and therefore most readily descriptive but could, in the right context, be "I came to love you" (within a narration). A descriptive discourse mode is confirmed by the verbless clauses of v. 2,

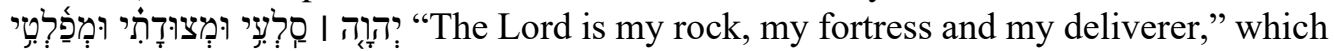
state a relationship rather than narrate an event. This prompts this opening section to be 
considered description (mimesis) as its discourse mode (indicated by a light grey background, reflecting both durative situation type and descriptive discourse mode).

The discourse mode and durative situation type of the predicate (verb and object argument together) אֶר "I love you" are confirmed by the yiqtol conjugation, making it an unmarked description. The remaining feature to identify, then, is that of time

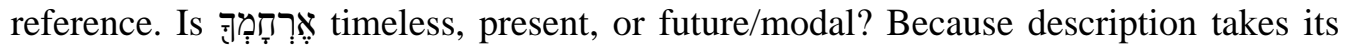
time reference from context, we must look to the superscription, the nature of the book of psalms as songs and prayers intended for the community to repeat, and the nature of the psalm itself. Viable options would be one-time reference (present time for the psalmist, per the superscription) and timelessness (or time unspecified), if the description is taken as characteristic (and not time-bound). For description, the time reference derives not from the verbal morphology, but the larger context. Literary coherence must pick up where grammar left off, to choose between the present or timelessness.

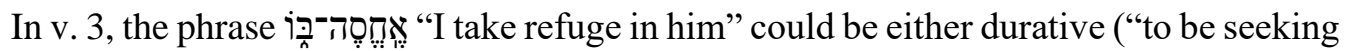
refuge," an activity) or punctual ("to attain refuge," an achievement) in English. The triumphal tone argues against the durative of currently "seeking refuge" and indicates a punctual: a semelfactive. The punctual situation type within a descriptive discourse mode can become iterative: "in whom I regularly seek refuge."

The default morphology for a punctual situation type is qatal. The combination of a punctual event with yiqtol morphology tends to yield either continuous aspect (in narration) or an iterative event (in description). Therefore, the combination of light grey morphology (yiqtol) embedded within dark grey situation type (punctual) embedded within light grey background (description) has the effect of converting the default onetime punctual (semelfactive) to an iterative action. This iterative action functions to describe a relationship (between the psalmist and God), alongside the verbless clauses also characterising this relationship.

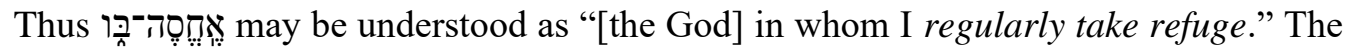
verb form brings the non-prototypical situation (punctual, in this case) closer to the prototype for the discourse mode (description, in this case). This is done by using the default verbal conjugation of the discourse mode (yiqtol, for description) for the verb

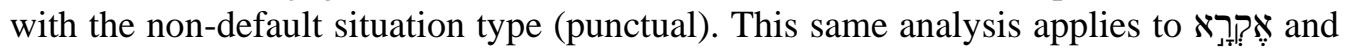

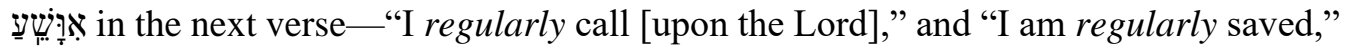
respectively. They are consequently also represented the same: by light grey verbs within dark grey boxes embedded within the light grey of the overall description.

In vv. 5-6, the situation changes. Instead of describing the relationship between God and the psalmist, circumstances are now described, in which the cords of death threatened and assailed him. 


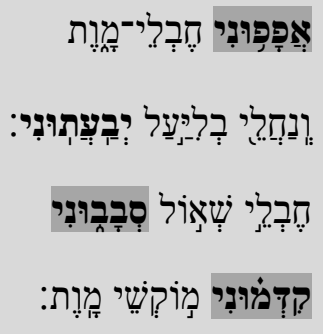

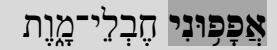

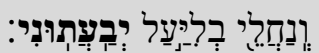

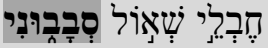

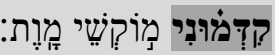

The cords of death had encompassed me;

The torrents of destruction assailed me;

The cords of Sheol had entangled me;

The snares of death had confronted me.

Figure 2: Psalm 18:5-6 presented according to situation type and verbal conjugation

The French Louis Segond translation puts all four verbs of these two verses into the plus-que-parfait, the pluperfect, thus understanding them to be (durative) accomplishments in the past.

4 Les liens de la mort m'avaient environné,

Et les torrents de la destruction m'avaient épouvanté ;

5 Les liens du sépulcre m'avaient entouré,

Les filets de la mort m'avaient surpris. (LSG)

When an accomplishment (a durative situation) is either put in the past or perfectivised, in description it can become a resultant state ("I became encompassed by the cords of death" with the English passive conveying the sense of state) or in narrative it can take on an achievement profile ("the cords of death managed to encompass me") (cf.

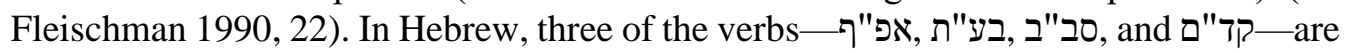
expressed with qatal forms and one-בעירו-with yiqtol.

Qatal morphology with punctual situation types tends to be simple past (in English terminology), but qatal morphology with durative situation types, as we have here, tends to express a perfect form (pluperfect, in a past context), as might be expected with punctual situation types preferring narrative (and preterites) and durative situation types preferring description (and perfects). The (plu)perfect renderings above recognise the description discourse mode here: the reference point does not advance with successive events.

Were one to continue a putative present time reference from the preceding verses,

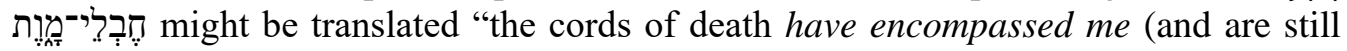
doing so)." Were one to posit past time reference, then "the cords of death had encompassed me" becomes the setting for an ensuing story. The identical clauses containing qatal verbs (and the yiqtol form, addressed below) could mean either; the time reference must come from the context. Since the psalmist is rejoicing because God has saved him (whether once or regularly, v. 3), a present setting seems incongruous. Instead, it would seem vv. 4-5 provide a setting for a past example (i.e., "the cords of death had encompassed me") that illustrates when God did save him. By this (literary) reasoning we conclude that the time reference for vv. $4-5$ is past. Whereas vv. 1-3 was 
a description either present or unspecified as to time, vv. 4-5 is a description placed in past time in order to set up the ensuing narrative. The semantics of distress, along with the qatal morphology (which converts the accomplishment [durative situation] into a resultant state) pull the situation away from its prototype (present description) into the past.

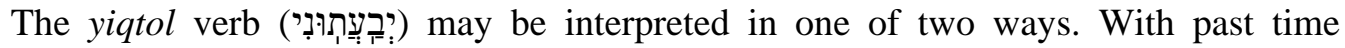
reference already established, the yiqtol form here might simply express continuous aspect for an activity, "the torrents of destruction were assailing me." If the

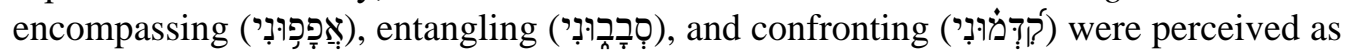

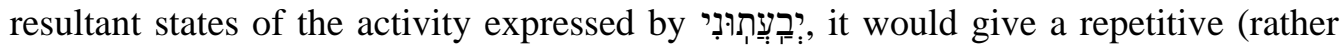
than continuous) profile to the assailing: "because the torrents (continued to) assail me, the cords managed to encompass me, entangle me and confront me."

The second interpretation is that of a grammatical merism, ${ }^{24}$ a literary device whereby either two items from a series are chosen in order to represent the whole (e.g., אֶת "the stone and the tree" [Jer 3:9] to refer to all idols), or a whole is divided

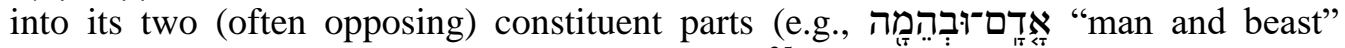
[Ps 36:7] to refer to all created living things). ${ }^{25} \mathrm{~A}$ grammatical merism refers to opposing grammatical forms used in combination in order to express not only their separate meanings but a larger totality of meaning, viz., "The cords of death had encompassed me; the torrents of destruction utterly assailed me."

Psalm 18:7 presents us with the hallmark of this chapter. The content of this verse epitomises an advancing reference point (with successive actions), which indicates a narrative discourse mode. The predicates headed by the verbs ת are punctual situation types. And yet, where we would have anticipated a qatal (or wayyiqtol) form for a narrative, the verbs in v. 6 all have yiqtol morphology. This verse contains a prototypical sequence of punctual events, but they are not narrated with prototypically past-tense forms.

24 Robar (forthcoming).

25 Schökel (2000, 83-84). The most exhaustive treatment of merism in the Hebrew Bible is by Krašovec (1977). Elsewhere, he states that one of the most important characteristics of merism is that it is a "substitution for abstract words [sic] 'all,' 'every,' 'always,' etc.," (Krašovec 1983, 232). See also Krašovec (2013). 


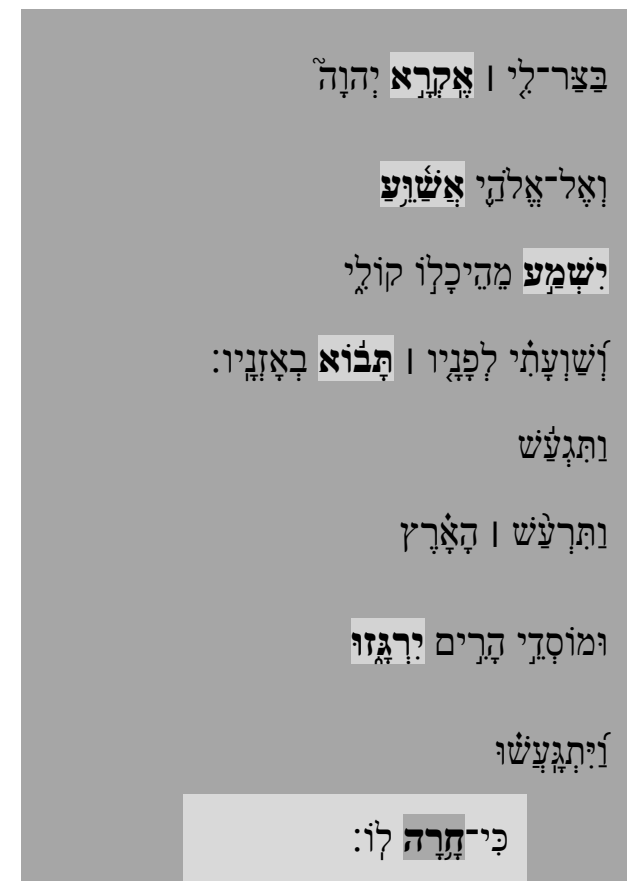

When distress was upon me, I called to the Lord;

to my God I cried for help.

He heard my voice from his temple;

And my cry to him reached his ears.

Then (the earth) reeled

And rocked;

The foundations of the mountains trembled

And quaked

Because he was angry.

Figure 3: Psalm 18:7-8 presented according to situation type and verbal conjugation

The referential (past tense, perfective aspect), textual (linked events, foreground), and metalinguistic (diegesis) parameters are all specified by the context, which suggests that the linguistic function affected by these yiqtol forms is in the "expressive" layer of language. I propose that the choice of yiqtol morphology here neutralises the parameters "distant" and "objective" in Table 1 above. Prototypical narrative events are presented objectively, as if distant, but these actions are presented with a sense of "nearness" or "subjectivity." Just as the present tenses in a conversational English story (as above) can nudge history toward performance, so too do these yiqtol forms. The effect of the verbal morphology here is to draw the punctual situation away from the related features of being distant and objective. That is, the effect of the verbal morphology is to draw the situation away from some of its prototypical features.

The subordinate clause in v. 8, בִּי־חָרָה לִ embeds a discourse unit within the larger narrative. This embedded unit is durative (stative) in situation type and descriptive in discourse mode (no advancing reference point). Time reference is derived from the embedding context (i.e., narrative, past tense), since the description itself has no indication for tense. As above in vv. 4-5, qatal morphology with a durative situation provides for a perfect of resultant state, which is not time-bound. 


\section{Conclusion}

Verbal morphology is more than the referential categories of tense and aspect, and even the expressive category of (ir)realis. Verbal conjugations represent a cluster of properties, as laid out in Table 1, which then interact with the cluster of properties of the surrounding discourse context. The result of this interaction, this paper proposes, is that morphological forms have the effect of either (1) drawing non-prototypical situations closer to the prototype, or (2) drawing situations farther away from the prototype. $^{26}$

\section{References}

Al-Heeh, S. 2020. "Affiliations of Verb Tense, Sentence Pattern and Language Style Shifts in the Noble Qur'an: Some Deep Linguistic Intuitiveness.” IAR Journal of Humanities and Social Science 1 (3): 144-55.

Andersen, Henning. 2001. "Markedness and the Theory of Linguistic Change." In Actualization: Linguistic Change in Progress, edited by Henning Andersen, 21-57. Philadelphia, PA: John Benjamins. https://doi.org/10.1075/cilt.219.02and

Comrie, B. 1976. Aspect. Cambridge Textbooks in Linguistics. Cambridge: Cambridge University Press.

Comrie, B. 1985. Tense. Cambridge Textbooks in Linguistics. Cambridge: Cambridge University Press.

Cook, J. A. 2012. Time and the Biblical Hebrew Verb: The Expression of Tense, Aspect, and Modality in Biblical Hebrew. Winona Lake: Eisenbrauns. https://doi.org/10.1515/9781575066813

Dancygier, B. 2011. The Language of Stories: A Cognitive Approach. Cambridge: Cambridge University Press. https://doi.org/10.1017/CBO9780511794414

Dixon, R. M. W. 2005. A Semantic Approach to English Grammar. Oxford: Oxford University Press.

Dixon, R. M. W. 2009. Basic Linguistic Theory: Methodology. Vol. 1. Oxford: Oxford University Press.

Dixon, R. M. W. 2012. Basic Linguistic Theory: Further Grammatical Topics. Vol. 3. Oxford: Oxford University Press.

26 This paper was first presented at the annual conference of the Society of Biblical Literature (online) in 2019. My sincere thanks belong to Joseph Habib for his tremendous help in researching and editing this paper. 
Evans, V. 2007. A Glossary of Cognitive Linguistics. Edinburgh: Edinburgh University Press.

Evans, V., and M. Green. 2006. Cognitive Linguistics: An Introduction. Edinburgh: Edinburgh University Press.

Fauconnier, G. 1997. Mappings in Thought and Language. Cambridge: Cambridge University Press. https://doi.org/10.1017/CBO9781139174220

Fleischman, S. 1982. The Future in Thought and Language: Diachronic Evidence from Romance. Cambridge Studies in Linguistics 36. Cambridge: Cambridge University Press.

Fleischman, S. 1989. “Temporal Distance: A Basic Linguistic Metaphor.” Studies in Language. 13 (1): 1-50. https://doi.org/10.1075/sl.13.1.02fle

Fleischman, S. 1990. Tense and Narrativity: From Medieval Performance to Modern Fiction. Austin, TX: University of Texas Press. https://doi.org/10.7560/780903

Gentry, P. J. 1998. "The System of the Finite Verb in Classical Hebrew." Hebrew Studies 39: 7-39. https://doi.org/10.1353/hbr.1998.0003

George, T. 2020. "Hermeneutics." The Stanford Encyclopedia of Philosophy (Winter 2020 edition). Edited by Edward N. Zalta.

https://plato.stanford.edu/archives/win2020/entries/hermeneutics/.

Halliday, M. A. K., and Ruqaiya Hasan. 1976. Cohesion in English. London: Longman.

Haspelmath, M. 2006. "Against Markedness (And What to Replace It With).” Journal of Linguistics 42 (1): 25-70. https://doi.org/10.1017/S0022226705003683

Hatav, G. 1997. Semantics of Aspect and Modality: Evidence from English and Biblical Hebrew. Amsterdam: John Benjamins. https://doi.org/10.1075/slcs.34

Herman, D. 2009. Basic Elements of Narrative. Hoboken: Wiley-Blackwell. https://doi.org/10.1002/9781444305920

Jakobson, R. 1975. "Spatial Relationships in Slavic Adjectives." In Scritti in onore di Guiliano Bonfante, 377-82. Paideia: Editrice Brescia.

Janda, L. A. 2019. “Tense, Aspect and Mood." In Cognitive Linguistics-Key Topics, edited by Ewa Dąbrowska and Dagmar Divjak, 191-209. Berlin: De Gruyter. https://doi.org/10.1515/9783110626438-010

Joosten, J. 2012. The Verbal System of Biblical Hebrew: A New Synthesis Elaborated on the Basis of Classical Prose. Jerusalem: Simor.

Koopman, N. 2018. Ancient Greek Ekphrasis: Between Description and Narration. Five Linguistic and Narratological Case Studies. Leiden: Brill. https://doi.org/10.1163/9789004375130 
Krašovec, J. 1977. Der Merismus: im Biblisch-hebräischen und Nordwestsemitischen. Rome: Biblical Institute Press.

Krašovec, J. 1983. “Merism—Polar Expression in Biblical Hebrew.” Biblica 64 (2): 231-39.

Krašovec, J. 2013. "The Poetic and Narrative Shape of the Hebrew Bible and Literary Forms of Antithesis." Religious and Sacred Poetry: An International Quarterly of Religion, Culture and Education 1 (1): 23-39.

Langacker, R.W. 2008. Cognitive Grammar: A Basic Introduction. Oxford: Oxford University Press. https://doi.org/10.1093/acprof:oso/9780195331967.001.0001

Lee, E. 2020. The Logic of Narratives. Leiden: Brill. https://doi.org/10.1163/9789004423343

Lu, W. 2019. "Time, Tense and Viewpoint Shift across Languages: A Multiple-Parallel-Text Approach to 'Tense Shifting' in a Tenseless Language." Cognitive Linguistics 30 (2): 377-97. https://doi.org/10.1515/cog-2018-0039

Lyons, C. G. 1983. "Suzanne Fleischman, The Future in Thought and Language: Diachronic Evidence from Romance.” Journal of Linguistics 19 (2): 481-84. https://doi.org/10.1017/S0022226700007842

Moomo, D. O. 2004. "'The Meaning of the Biblical Hebrew Verbal Conjugation from a Crosslinguistic Perspective." PhD diss., University of Stellenbosch.

Myhill, J. 1992. Typological Discourse Analysis: Quantitative Approaches to the Study of Linguistic Function. Oxford: Blackwell.

Nijk, A. A. 2019. "Bridging The Gap between The Near and The Far: Displacement and Representation." Cognitive Linguistics 30 (2): 327-50. https://doi.org/10.1515/cog-2018-0042

Notarius, R. 2013. The Verb in Archaic Biblical Poetry: A Discursive, Typological, and Historical Investigation of the Tense System. Leiden: Brill. https://doi.org/10.1163/9789004253353

Robar, E. 2014. The Verb and the Paragraph in Biblical Hebrew: A Cognitive-Linguistic Approach. Leiden: Brill. https://doi.org/10.53751/001c.29373

Robar, E. 2021. "The Rise of Wayyiqtol.” In New Perspectives in Biblical and Rabbinic Hebrew, edited by Aaron Hornkohl and Geoffrey Khan, 241-74. Cambridge: Open Book Publishers. https://doi.org/10.11647/obp.0250.10

Robar, E. Unpublished manuscript. "Yiqtol and Qatal as a Grammatical Merism."

Rubin, E. 2001. "Figure and Ground." In Visual Perception: Key Readings in Cognition, 225-29. Philadelphia: Psychology Press. 
Sakita, T. 2002. Reporting Discourse, Tense and Cognition. Leiden: Brill. https://doi.org/10.1163/9789004487215

Saur, M. 2014. Die Königspsalmen: Studien zur Entstehung und Theologie. Berlin: De Gruyter.

Schökel, L. A. 2000. A Manual of Hebrew Poetics. Rome: Editrice Pontifico Instituto Biblico.

Smith, C. 1997. The Parameter of Aspect. Dordrecht: Kluwer. https://doi.org/10.1007/978-94-011-5606-6

Talmy, L. 2000. Toward a Cognitive Semantics Volume I: Concept Structuring Systems. Vol. 1. Cambridge, MA: The MIT Press. https://doi.org/10.7551/mitpress/6847.001.0001

Traugott, E. C. 1982. "From Propositional to Textual and Expressive Meanings: Some Semantic-Pragmatic Aspects of Grammaticalization." In Perspectives on Historical Linguistics, edited by Winfred P. Lehmann and Yakov Malkiel, 245-71. Amsterdam: Benjamins. https://doi.org/10.1075/cilt.24.09clo

Trubetzkoy, N. S. 1939. Grundzüge Der Phonologie. Göttingen: Vandenhoeck \& Ruprecht.

Trubetzkoy, N. S. 1969. Principles of Phonology. Translated by Christiane A. M. Baltaxe. Berkley: University of California Press.

Vendler, Z. 1957. "Verbs and Times.” The Philosophical Review 66 (2): 143-60. https://doi.org/10.2307/2182371

Verhagen, A. 2019. "Shifting Tenses, Viewpoints, and the Nature of Narrative Communication." Cognitive Linguistics 30 (2): 351-75. https://doi.org/10.1515/cog-2018-0058

Waugh, L. R. 1982. "Marked and Unmarked: A Choice between Unequals in Semiotic Structure.” Semiotica 38 (3-4): 299-318. https://doi.org/10.1515/semi.1982.38.3-4.299

Wolf, W. 2007. "Description as a Transmedial Mode of Representation: General Features and Possibilities of Realization in Painting, Fiction and Music." In Description in Literature and Other Media, edited by W. Wolf and W. Bernhart, 1-87. Amsterdam: Rodpoi. https://doi.org/10.1163/9789401205214_002

Wolfson, N. 1978. "A Feature of Performed Narrative: The Conversational Historical Present." Language in Society 7 (2): 215-37. https://doi.org/10.1017/S0047404500005534

Wolfson, N. 1979. "The Conversational Historical Present Alternation.” Language 55 (1): 168-82. https://doi.org/10.2307/412521 